ANASSESSMENT OF BASEL II PROCYCLICALITY IN MORTGAGE PORTFOLIOS

Jesus saurina and Carlos turchante.

Documentos de Trabajo. N. 0712

\title{
BANCOTESPANA
}

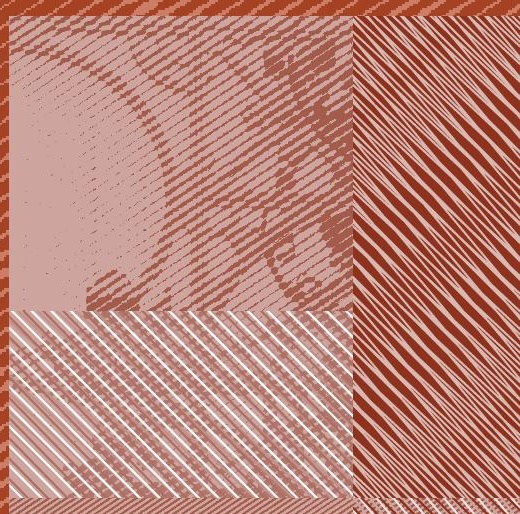

\author{
Eurosistema
}


AN ASSESSMENT OF BASEL II PROCYCLICALITY IN MORTGAGE PORTFOLIOS 


\section{AN ASSESSMENT OF BASEL II PROCYCLICALITY IN MORTGAGE}

PORTFOLIOS

Jesús Saurina and Carlos Trucharte ${ }^{(*)}$

BANCO DE ESPAÑA

$\left.{ }^{*}\right)$ This paper is the sole responsibility of its authors and the views presented here do not necessarily reflect those of Banco de España. The authors gratefully acknowledge useful and helpful comments from W. Francis, G. Jiménez, P. Kupiec, W. Lang, G. Pennacchi, R. Repullo, A. Rodríguez, H. Unal, an anonymous referee, and those of participants at the FDIC 6th Bank Research Conference.

(**) Address for correspondence: Jesús Saurina. c/ Alcalá, 48, 28014 Madrid, Spain. Tel.: + 3491338 5080; e-mail: jsaurina@bde.es. 
The Working Paper Series seeks to disseminate original research in economics and finance. All papers have been anonymously refereed. By publishing these papers, the Banco de España aims to contribute to economic analysis and, in particular, to knowledge of the Spanish economy and its international environment.

The opinions and analyses in the Working Paper Series are the responsibility of the authors and, therefore, do not necessarily coincide with those of the Banco de España or the Eurosystem.

The Banco de España disseminates its main reports and most of its publications via the INTERNET at the following website: http://www.bde.es.

Reproduction for educational and non-commercial purposes is permitted provided that the source is acknowledged.

\section{(C) BANCO DE ESPAÑA, Madrid, 2007}

ISSN: 0213-2710 (print)

ISSN: 1579-8666 (on line)

Depósito legal: M.26321-2007

Unidad de Publicaciones, Banco de España 


\section{Abstract}

In this paper we develop a probability of default (PD) model for mortgage loans, taking advantage of the Spanish Credit Register, a comprehensive database on loan characteristics and credit quality. From that model, we calculate different types of PDs: point in time, PIT, through the cycle, TTC, average across the cycle and acyclical. Then, we compare capital requirements coming from the different Basel II approaches. We show that minimum regulatory capital under Basel II can be very sensitive to the risk measurement methodology employed. Thus, the procyclicality of regulatory capital requirements under Basel II is an open question, depending on the way internal rating systems are implemented and their output is utilised. We focus on the mortgage portfolio since it is one of the most under researched areas regarding the impact of Basel II and because it is one of the most important banks' portfolios.

JEL: E32, G18, G21.

Keywords: procyclicality, Basel II, rating systems, mortgages. 
How will capital requirements evolve with Basel II? This is a key question to evaluate the real impact of the change in the capital requirements framework brought about by the release in June 2004 (updated June 2006) by the Basel Committee on Banking Supervision (BCBS) of its International Convergence of Capital Measurement and Capital Standards, the so-called Basel II framework. Bankers, regulators, and academics have tried to answer this question during the process of discussion of Basel II (beginning in 1999) with different aims. Bankers are concerned about the impact of Pillar 1 credit, market and operational risk requirements on the capital level of each bank as well as the additional impact that Pillar 2 could have on minimum requirements stemming from Pillar 1 . Moreover, Pillar 3 transparency requirements regarding risk exposure have also been a concern for banks. Regulators have focused their interest on obtaining capital requirements proportional to risk in order to make sure that bank managers, and bank stakeholders have, in general, enough incentives to measure and manage risk properly. Academics and some central banks have shown concerns regarding the impact that Basel II might have on the aggregate behaviour of banks along the cycle, especially in financial stability terms.

A more targeted question focuses on the procyclicality of Basel II. A series of questions arise from this. Are capital requirements under Basel II going to be excessively procyclical? How much will capital requirements vary from one period to the next? Will that put too much pressure on the soundness and stability of financial systems of different jurisdictions? Will capital requirements become binding during recessions? These questions have attracted much attention from bankers, regulators, central banks, and academics ${ }^{1}$. The evidence provided up to now has been, in general, supportive of procyclical concerns. However, Gordy and Howells (2006) challenge this view, arguing that collateral, maturity, bank behaviour and Pillar 2 and 3 may substantially temper Basel II procyclicality, and they conclude by proposing a specific solution to it.

The objective of this paper is to develop a methodology for the analysis of capital requirements under Basel II that will allow us to focus on the procyclicality issue, and to assess with real data the impact of various ways to compute probabilities of default (e.g. point-in-time, through-the-cycle, averages along the cycle, corrected for the cycle, etc.). One of the most important conclusions that different supervisors and regulators have observed in analysing simulated Basel II capital requirements is that there is a wide dispersion among credit institutions that does not correspond with identifiable differences in risk. In fact, the various methods or even the different alternatives that banks use to estimate their key credit risk parameters (i.e. the probability of default), are to some extent responsible for the wide variability and uncertainty surrounding the internal ratings-based approach (IRB) proposed by the BCBS to calculate regulatory capital.

Furthermore, considering that within the wide range of possibilities of calculation of PDs some are clearly influenced by the prevailing economic conditions, major fluctuations

\footnotetext{
1. See, among others, Borio, Furfine and Lowe (2001), Ervin and Wilde (2001), Allen and Saunders (2004), Amato and Furfine (2004), Ayuso, Pérez and Saurina (2004), Kashyap and Stein (2004), Taylor and Goodhart (2004), Catarineu-Rabell, Jackson and Tsomocos (2005), Gordy and Howells (2006), Repullo and Suárez (2006) and White (2006). Separately, Pennacchi (2005) and Madan and Unal (2006) study the procyclicality but, in this case, with regard to deposit insurance.
} 
and high variability among credit institutions' requirements may take place as a result of Basel II. Consequently, the aim of this paper is general and it may be used to assess corporate and retail portfolios. However, here we focus on one of the most under researched areas regarding Basel II, which is the potential procyclicality of mortgage portfolios. This lack of research may be a consequence of the lack of data even though mortgages are, for retail banks and many internationally active banks, one of their largest portfolios. Moreover, the cyclicality of the mortgage portfolio is also interesting because the largest contribution to the reduction in IRB minimum regulatory capital, according to the latest quantitative studies, comes from this specific portfolio [see BCBS (2006a)].

First, we develop a classification system which encompasses a model that estimates a probability of default for each obligor: that is, there is a model which assigns an individual PD for each particular borrower. Second, we evaluate different rating systems based on the way the PD is calculated: PD estimations can be used directly (i.e. point in time), averaged across the cycle using different criteria, or we can use the worst-case PDs (i.e. through the cycle) $)^{2}$. Finally, we compare capital requirements using different Basel II formulas and approaches (i.e. Standardized and IRB). The results provided in this paper show that capital requirements under Basel II may be very sensitive to the risk measurement methodology. Thus, the procyclicality of Basel II is an open question, depending on the way banks' internal rating systems are implemented: specifically, on how the main inputs of the Basel II formulas, basically PDs, are calculated.

We have information that covers a long period of time which allows us to evaluate the impact of Basel II capital requirements on mortgage portfolios along a full business cycle, including a collapse of house prices. The information comes from a single database: the Spanish Credit Register (CIR) run by Banco de España ${ }^{3}$. It includes information on almost the whole population of mortgages granted by all Spanish credit institutions. Therefore, we can perform a global analysis for the whole banking system.

The rest of the paper is organized as follows. In Section 2 we briefly review the procyclicality discussion under Basel II and the literature on mortgage capital regulation. Section 3 presents the PD estimation methodology employed in this paper and the database which supports it. Section 4 shows the results in terms of distributions of PDs along time. Section 5 focuses on capital requirements using as input to calculate them the PDs obtained in the previous section. Finally, Section 6 provides a conclusion.

2. See Heitfield (2005) for a formal discussion of point-in-time and through-the-cycle rating systems.

3. Jiménez and Saurina (2004), Trucharte (2004) and Jiménez, Salas and Saurina (2006) contain a detailed description of the Spanish Credit Register. 


\section{Procyclicality and the mortgage market}

The impact of Basel I on lending policies and on economic activity has been subject to intense research. Empirical papers have found evidence of a credit crunch at the beginning of the nineties in the US. Some papers consider that lending contraction due to a capital crunch may be attributed to Basel I capital requirements ${ }^{4}$. During the discussion of Basel II proposals, some analysts have stated concerns regarding various issues, procyclicality was among the most controversial ones. The underlying argument goes as follows: procyclicality would basically translate into lower capital requirements when favourable economic conditions prevail, and into higher requirements under unfavourable conditions. This could have an undesirable effect on the overall economy if banks, according to a more risk-sensitive regulatory capital system, are obliged to significantly alter their lending behaviour.

To take an example, if credit models overstate default risk during recessions, capital requirements will increase in consequence. As a result, banks will respond by tightening their credit standards and, in the last instance, by reducing their volume of lending to comply with the higher ratios of the new capital regime. Economic agents (basically households and firms) will experience serious difficulty to recover under these adverse economic conditions. This means that the most unfavourable part of the business cycle may become more accentuated if banks cut down on credit, aggravating the general economic situation and magnifying the economic downturn. The opposite will occur in the benign part of the business cycle. A good summary of arguments supporting this view, focusing on the content of Basel II, can be found in Taylor and Goodhart (2004). Alternative arguments, again focusing on the Basel II proposal, appear in Gordy and Howells (2006).

In order to address procyclicality, Gordy and Howells (2006) argue that the best option for supervisors is to smooth the output (i.e. smooth the final capital requirements derived from the Basel II proposal) instead of the inputs (i.e. the PDs that enter IRB formulas) or the formulas in themselves (flattening of the curves). They propose an autoregressive capital requirement formula or another directly tied to the position of the economic cycle. Goodhart (2005) claims that a second instrument is needed to maintain financial stability, since interest rates (the first instrument) are devoted to control the inflation. He underlines that such an additional instrument should have countercyclical characteristics. Jiménez and Saurina (2006) argue for a countercyclical loan loss provision that, in fact, could also work as a capital requirement throughout Pillar 2.

Note that, even if the new capital requirements were procyclical as described above, it is necessary that particular conditions hold for there to be ill effects. First, bank managers should not react to the cyclical profile of their capital buffer. Second, it should not be excessively costly for banks to raise preference shares or subordinated debt during downturns. Furthermore, the cyclical effect must be significant ${ }^{5}$ and the capital buffer decline must have a significant impact on lending policies ${ }^{6}$. Finally, the reduction in lending should

4. See, among others, Bernanke and Lown (1991), Berger and Udell (1994), Peek and Rosengren (1995).

5. Ayuso, Pérez and Saurina (2004) find a significant but small cyclical impact of GDP on the capital buffer hold by Spanish banks.

6. Gambacorta and Mistrulli (2004) find evidence of the impact of capital on lending policies in a sample of Italian banks while Altumbas, Fazylow y Molineux (2002) and Ehrmann et al. (2003) do not find support for the hypothesis that poorer capitalized banks suffer more under tight monetary conditions. 
only be a supply side factor (i.e. not induced by a weak demand for loans) and that non-financial firms should not be able to substitute bank funding by trade credit and/or resort to short or long term markets (e.g. commercial paper, bonds, asset backed securities, etc.) ${ }^{7}$.

Before getting real data based on Basel II requirements, which will happen at the earliest in the European Union in 2007 for the more basic approaches and in 2008 for the more advanced ones ${ }^{8}$, most effort has been concentrated on trying to anticipate the future behaviour of banks using past portfolio information. These attempts have focused, overwhelmingly, on the corporate (and sovereign) portfolios, those for which there is more publicly available information on credit quality [among others: Segoviano and Lowe (2002), Goodhart, Hofmann and Segoviano (2004), Kashyap and Stein (2004) and Goodhart (2005)]. Some work has been done on the retail SME portfolio [e.g. Dietsch and Petey (2002), Saurina and Trucharte (2004) and Jacobson, Jesper and Roszbach (2006)] and credit cards [Lang, Mester and Vermilyea (2006)], while mortgages are very little explored.

Empirical work on Basel II procyclicality has usually been based on corporate portfolios and, normally, on Moodys-KMV ratings. Here, for the first time in the literature, we evaluate the potential cyclical behaviour of Basel II capital requirements in mortgage portfolios, using a prototype of rating system in the same vein as those that banks employ to classify their mortgage obligors when granting a loan. These, in the future, will be the ones utilised for qualification for the more advanced Basel II approaches.

Mortgage markets have been widely studied. Allen (2004) surveys this literature as well as more general Basel II issues (i.e. procyclicality, incentives, securitization, and capital arbitrage). It also focuses on Basel impact on mortgage markets, although the papers she cites (where emphasis is devoted to the German market) are quite different from our paper, since none of them develops a classification system in order to determine capital requirements for mortgage portfolios under Basel II premises. Similarly, our paper departs from Calem and LaCour-Little (2004) who simulate economic capital for mortgage portfolio and conclude that Basel I or Basel II standardized approach, which offer little risk differentiation, result in significant divergence between economic and regulatory capital.

7. A summary of these arguments is in Viñals (2006).

8. The Basel II schedule is even more delayed for certain jurisdictions, e.g, the US. 


\subsection{PD equation for borrowers}

The first step consists of the developing of a PD model for mortgage borrowers. We do not have detailed information on borrowers' social and financial characteristics (marital status, type of employer, income, wealth, etc.). However, we do have information in the Credit Register that may be used to characterize the risk profile of borrowers. To account for the business cycle, we use contemporaneous real GDP growth rates. The PD equation we estimate is the following:

$P D_{i t}=\beta_{1} R_{I S K B O R R}+\beta_{2} L_{I Q B O R R}+\beta_{3} G D P G_{t}+\beta_{4} C O N T R O L+\eta_{i t}$

The endogenous variable is a dichotomous (zero-one) variable which takes value 1 if a borrower defaults in year $\mathrm{t}, 0$ otherwise. It has to be clearly stated that the estimated PDs are a measure of the likelihood that an obligor will default within a certain assessment horizon. This horizon is fixed at a one-year period. Under this premise, the endogenous variable is constructed, also assuming that a defaulted obligor is defined in a similar way as in Basel $I^{9}$ : at least 90 days overdue, failing to meet financial obligations on a certain loan. If a borrower has several mortgages, failure to meet payments on any of them means that this borrower is in default. Based on that, we estimate a logistic transformation of equation (1) by the standard maximum likelihood maximization process.

Among the explanatory variables, RISKBORR it is a vector of risk profile characteristics of each borrower evaluated at time t. In particular, we use DEFHIST it as a variable which informs whether a certain borrower has defaulted in any period previous to the one used to fix the one-year assessment period for which the PD is calculated (i.e. possible failure in $\mathrm{t}-2, \mathrm{t}-3 . .$.$) . Additionally, this variable is weighted by the distance in time$ since the default of that obligor took place. Thus, the more distant in time the default took place, the less it counts, which seems in line with banks' credit policy practices in general.

OVERHIST it is another risk profile variable which accounts for the possibility that a borrower has been delinquent in previous periods $(t-1, t-2 \ldots)$. That is, OVERHIST represents borrowers overdue on their loans who finally meet their financial obligations before the 90-day threshold, that is, before becoming officially defaulted. As for the previous variable, this one is also weighted by the distance in time a borrower committed delinquency on his loan. It has to be noted that many of the problems that are behind an overdue loan are "technical" ones, spanning only a few days as a result of mistakes or lack of monitoring of balances, accidental cash shortage, holidays, etc. Nevertheless, we include this risk profile variable since a risk averse borrower will always hold a minimum buffer for unexpected events to avoid, precisely, becoming overdue.

We also include as an explanatory variable the rate of change in the latter variable (CHANOVERHIST ${ }_{i t}$ ). Its inclusion intends to anticipate future declines in borrowers' ability to repay their mortgages. Finally, the variable AGEit measures the age of each loan which usually coincides with the number of years each borrower has been in the Credit Register,

9. See BCBS (2006 b), paragraph 452 . 
that is, it represents his age as a borrower. As will be shown later, there is a particular relationship between the age of a loan and its probability of default, showing that, in general, higher rates of default take place during the first years of a mortgage. After that period of time (three to four years), the rate of default decreases progressively with the age of the $\operatorname{loan}^{10}$.

We also include in equation (1) a vector of variables that proxy for the liquidity constraints that a borrower may face (LIQBORR $i$ ). Variable UTIL it is the quotient between the amount of credit drawn by a borrower and the total available amount (credit line). Some mortgages are sold as a credit line facility where the borrower can withdraw money at any time against the amount already repaid. The collateral (i.e. the house that constitutes the object of the mortgage) remains pledged to the credit line. The more a borrower withdraws, the more liquidity constrained he may be. The second liquidity variable is NUMBANKS it, the number of banks with which the borrower has lending relationships. Note that we focus on individual borrowers, not banks. As a result, we hypothesize that the higher the number of banks a borrower is related to, the more constrained he is in terms of liquidity.

The above-mentioned risk profile and liquidity variables are only a subset of those we have used. Apart from levels or first differences, we have tried continuous and discrete specifications. Given that many of these variables are highly correlated, we previously ran univariate regressions (borrower mortgage default as a function of a variable at a time). From those regressions we took the variables with the highest explanatory power. Later on, we ran equation (1) using combinations of the selected variables. Based on forecasting capacity ${ }^{11}$, the main guide for banks when they develop their scoring/rating systems, we finally determined the set of variables included in the final multivariate regression.

Note that banks, in developing their internal models for mortgage defaults, have much more detailed information on each borrower (basically, income and social information). We are hypothesizing here that the past experience of a borrower, both in terms of overdue and defaulted loans, as well as the age in the Credit Register, are a sufficient statistic for that information. Thus, the main difference between our benchmark model and those of banks lies in the accuracy of default forecasts (i.e. the percentage of defaulted and non-defaulted borrowers properly classified as such). Note that this is less relevant in our paper since we focus on the behaviour of PDs along the cycle and the different ways they are calculated, as well as the dispersion they may create in determining regulatory capital. There is no reason to think that our sufficient statistic performs differently in upturns and downturns.

Our cyclical variable in model (1) is the real GDP growth rate (GDPGt). Among the CONTROL variables, we have included a dummy that accounts for the region of the borrower. We also control for the type of mortgage lender: commercial bank, savings bank, credit cooperative or credit finance establishments. Savings banks (not-for-profit banks) hold half of the market share in mortgages. Moreover, the risk profile may change according to the ownership structure of the bank [Delgado, Salas and Saurina (2006)]. We also include a dummy variable (REG99) that takes the value of 1 from 1999 onwards and 0 otherwise, in order to reflect the change in the report of defaulted loans in the database. After 1999, any defaulted amount is reported while before that year only defaults above 6,000 euros were reported. The expected sign of the dummy variable is positive.

10. A similar behaviour, an inverted U-shaped curve between the age of a loan and its probability of default, is found on credit card delinquencies by Gross and Souleles (2002).

11. This predicting capacity has to be understood in terms of accurate classification of defaulted and non-defaulted borrowers. 


\subsection{Database}

The database used for this study is the Credit Register of the Bank of Spain (CIR). The CIR records monthly information on all credit operations granted by credit institutions (commercial banks, savings banks, credit cooperatives and specialised credit institutions) in Spain for a value of over $€ 6,000$. The CIR's data structure distinguishes between credits given to firms and those to individuals ${ }^{12}$. The $\mathrm{CIR}$ includes information on the characteristics of each loan, including the following: instrument (trade credit, financial credit, leasing, etc.), currency denomination, maturity, existence or not of guarantees or collateral, type of guarantor (government or credit institution), the coverage of the guarantee, the amount drawn and undrawn of a credit commitment and, finally, but very importantly, whether the loan is current in payment or past due (distinguishing between delinquency and default status). The CIR also includes information relating to the characteristics of borrowers: province of residence and, for firms, the industry in which they operate. There is no information regarding the interest rate of the loan.

Here, we focus on mortgages to individuals. These are collateralized loans with maturity over five years. The time period covered goes from 1990 to 2004, which covers a whole business cycle in Spain, with a deep recession around 1993 and the corresponding upturn, even boom, during the nineties and the first years of the current decade. Given the very low threshold for a loan to be included within the CIR, we can be confident of having information about the entire population of mortgages in Spain. That means dealing with a vast amount of information (over 30 million loans) which makes it almost impossible to run any regression. Accordingly, we have cut down the population into another tractable one by choosing only a certain number of borrowers. A sampling procedure was carried out based on a very simple rule that produced a stratified sample that perfectly matches with the main characteristics of the entire population. After sampling the population of loans we are still left with almost 3 million mortgages. To the best of our knowledge, we are not aware of any paper that uses such an amount of information for modelling default probabilities of mortgages.

Table 1 shows some descriptive statistics of the whole population of mortgages as well as those of the sample chosen. Note that even though the default ratios (proportion of defaulted borrowers) may sometimes be quite low (below 1\%), given the amount of observations we have, this is not a problem for the estimation of model (1).

It can also be seen that the number of borrowers as well as the amount lent increases significantly along time, while the increase in the average size of the loan less than doubles. The problem loan ratio as well as the proportion of defaults (i.e. rough PD calculations from the population and the sample) follows a cyclical pattern reaching a maximum around 1993 (the recession year). The extremely low current levels show the strength of the business cycle in Spain and/or the change in banks' credit risk policies. From Table 1 we can conclude that there is an almost perfect matching between the main characteristics of the whole population and the sample we have taken from it.

\subsection{Results}

Table 2a, column 1, shows the results of the estimation of model (1). All the variables have the expected signs and are significant at the $99 \%$ level. The higher the risk profile of a borrower

12. There is a clear separation between the characteristics of loans to companies (mainly in terms of the size of the loan, maturity, collateral and default rates) and those loans granted to individuals, making it appropriate to treat each of the two groups separately. 
the higher the probability of default. Consequently, overdue loans (OVERHIST it and $\mathrm{CHANOVERHIST}_{\text {it) }}$ can be considered as a signal of future default (both in levels and rates of growth). Regarding other variables, the older a loan, the lower its probability of default ${ }^{13}$ (negative sign of the age variable). Taking into account liquidity issues, the higher the use of bank funds and the more lenders an individual resorts to, the higher the probability of default (positive sign for UTILit and NUMBANKSit). Thus, liquidity constraints also seem to play a role in mortgage defaults.

Commercial banks (omitted dummy variable of ownership type) are the least risky regarding mortgages, whereas credit finance establishments show the highest PD (not shown in the Table). The latter credit institutions hold a small market share (around 1\%) but they concentrate on riskier borrowers, maybe those who cannot obtain a mortgage from deposit institutions.

The sign of the cyclical variable included in the regression, GDP growth rate, is negative and significant, as expected. During downturns and recessions, mortgage defaults increase, declining in upturns. Therefore, PDs fluctuate along the cycle. In the next section we analyse how much they may vary depending on the way they are calculated. The borrowers' classification system is used as the basis for obtaining the different estimates of the PDs.

The second through fourth columns of Table $2 \mathrm{a}$ show that the former results are robust, both in terms of sign and significance, to changes in control variables. Column 2 shows the results of the regression when the type-of-lender dummies have been taken out. Column 3 excludes regional dummies and, finally, column 4 excludes both sets of dummies.

In addition, we have performed several robustness analyses on the results presented in Table 2a (not shown to save space). We also included an interest rate variable (both nominal and real). It is positive and significant in both cases but the accuracy of the model does not improve significantly. We have also excluded GDPG and included the interest rate with very similar quantitative results. We could probably have included other business cycle variables but, we might have lost clarity in modelling changes that take into account cyclical variables. This is why we stick only to the GDPG for the measurement of cyclical effects. More importantly, both the average level of PDs and their shape along time according to different rating methodologies do not change much irrespective of the macro variables that may be used.

Once the variables that determine an individual's possibility of defaulting have been established and their coefficients and signs within the multivariate model are known, it is desirable to establish certain performing measures for the estimated regression model in order to evaluate its classification power. Table $2 \mathrm{~b}$ shows the classification table of the final model. It can be observed along the main diagonal that the model correctly classifies approximately $77 \%$ of the borrowers included in the sample. In terms of alternative performing measures, the area under the ROC curve roughly reaches $78 \%$ which results in an Accuracy Ratio (AR) near to $57 \%^{14}$.

The previous classification power is obtained for the training sample. In order to test the consistency of the model a validation sample should be constructed using external

13. This is in line with firm defaults, where young firms have a higher mortality.

14. The AR measure determines the performance enhancement over the random model of the model under evaluation [model (1)] with respect to the ideal model. 
data (2005 data). The validation process simply consists of calculating the score of every borrower and comparing it with its observed default status. The results are reasonably close to those of the training sample (almost $77 \%$ of individuals were correctly classified) indicating a satisfactory classification capability of the estimated model. 
Once model (1) has been estimated, each borrower in the sample is assigned an individual PD based on the characteristics of the borrower (idiosyncratic factors) and on a macro variable (common cyclical factor). This allows us to rank each borrower according to his PD as well as to calculate alternative values for average PDs for the entire sample in order to evaluate their main properties and, finally, their procyclical implications.

The first PD obtained is the easiest to calculate (the point-in-time, PIT, PD). We can use the actual PD (that is, the ratio between the number of mortgage borrowers that default in year $t$, not having defaulted in the previous period, over the total number of borrowers with a mortgage) or the estimated (fitted) one using the regression model and the predictions extracted from it. Given the two available options, we choose the first one in order to use the most accurate possible information. In any case, the sample average PDs in both approaches are, as expected, very similar (1.1\% real and $1.2 \%$ fitted) as well as their shape along time.

Table 3, column 1 shows the PIT PD values. It can be seen that there is substantial variation in the recorded level of that PD along time. Around the recession, Spanish banks experienced relatively high default rates. On the other hand, by the end of the last decade and at the beginning of the current one, when a protracted period of economic growth combines with a significant increase in the number of mortgages granted by banks, the observed PDs are quite low. It should be noted that the Spanish economy experienced during the period analysed a structural change which led to entry into the European Monetary Union in 1999.

The second type of PD derived from the estimated classification system is the through-the-cycle one (TTC). According to Heitfield (2005), that PD is the one that would occur at the trough of the business cycle. This means that we have to use the value that the GDP growth rate took in year 1993, the most negative year in the sample, to calculate it. In fact, that year represents the worst recession that the Spanish economy has experienced in the last 40 years. Thus, to compute the PD we keep constant the GDPG variable at the 1993 level while allowing for changes in the other significant variables included in model $(1)^{15}$. Consequently, we obtain different individual TTC PDs as well as the overall one for each year. Table 3, second column, shows, as expected, that the average PD TTC is almost $80 \%$ higher than the PIT PD. However, taking into account how both PDs have been calculated, the profile along time of the TTC PD is much smoother than that of the PIT one.

The third column in Table 3 contains another smoothing type of PD (a long-run average PD). This is a cumulative average, where the PD attributed to each year is the simple average of the yearly averages of the fitted PDs up to that year. As can be observed, the sample average is not too far away from the sample average of the TTC PD. This result is mainly obtained by construction since we start with high levels of PDs that remain along the cycle, thus influencing the long-run average. A partial answer to this problem is to use a rolling (moving) average, with the drawback of not including in the average the first years of the sample that, in our case, constitute those of the recession. It should be noted that for the

15. The fitted $P D$ is obtained by substituting in model (1) the value that each explanatory variable takes, keeping the value of GDPG fixed at the 1993 level. 
rolling average PD volatility declines relative to PIT estimates the longer is the lag length applied.

The last two columns in Table 3 show different variations of how a rating system may be used to calculate PDs. These represent different cyclical corrections in the values of the fitted PDs. Particularly, the fourth column of Table 3 presents PD estimates determined when the value of the GDP growth rate variable in model (1) is substituted by its average during the entire sample period (cyclically corrected PD) ${ }^{16}$. Volatility, measured by the standard deviation, declines dramatically in comparison with PIT or even TTC estimates. However, the sample average PD across the period is very close to that of the PIT PD. The coefficient of variation, that is, the dispersion measure that controls for the level of the mean, shows roughly similar dispersion for the TTC PDs and the cyclically corrected ones, while the levels are much higher for the former than for the latter.

The last column of Table 3 shows what we could call an acyclical PD. This is calculated using a rating based on the prediction model (1) but excluding the cycle variable (GDPG $)$. That is, we reestimate model (1) without the cyclical variable and, subsequently, predict individual PDs in the absence of the common factor ${ }^{17}$. The results are almost identical if we exclude regional dummies (not shown). The sample average acyclical PD is very similar to the PIT one since we have smoothed away the large PDs during the recession. Nevertheless, the variability across PDs is higher for the PIT as a result of the relatively high values recorded in the early nineties. Accordingly, the volatility of the acyclical PDs is very low compared to that of the PIT one and, to some extent when compared to the volatility of the TTC PD.

Figure 1 shows the outcome of the five different ways of calculating PD from the estimated rating system. There are significant differences across the various approaches that produce significantly distinct Basel II capital requirements for mortgages. In the next section we analyse these requirements.

16. The cyclically corrected PD is obtained by substituting in model (1) the value that each explanatory variable takes in each year, keeping the value of GDPG fixed at its sample average value.

17. It should be noted that not all the cyclical component can be taken out of the rating system since a high number of the idiosyncratic variables are influenced by it. A pure acyclical rating system (and the PDs from it) would need all remaining variables to be free of the cycle, which for some cases would suppose the estimation of a complete different model. 


\subsection{Basel II risk parameters (PDs)}

In order to measure capital requirements under the IRB approach for mortgages it is necessary to make a hypothesis regarding the loss given default, LGD. Given the supervisory experience acquired from the various Quantitative Impact Studies (QIS) carried out by the BCBS in recent years, an LGD fixed at 15\% seems to be a reasonable figure. In any case, as this parameter enters lineally in the Basel II capital requirement formulas, whenever it is set to a certain value its impact will only be a matter of level. Its shape will change over time only if LGDs are also dependent on the business cycle ${ }^{18}$ and are calculated using a cycle-sensitive approach. This would provide different LGD values for different periods of time (e.g. downturn LGD estimates).

Table 4, first column, shows the capital requirements associated with a PIT PD. The fluctuation in capital figures is quite evident showing a substantial decline along the cycle. Compared with the new Standardized Approach regulatory requirements (2.8\% capital figure for mortgages), IRB capital requirements are slightly higher for recession years whereas for upturns they can be very considerably lower. It is important to bear in mind that the Spanish credit market has changed significantly during the last decade and that banks have significantly improved their risk management procedures. Nevertheless, even acknowledging the structural shift in the Spanish economy and the improvement in credit risk management, PIT capital requirements are bound to change significantly along the cycle. As argued by the extant literature and by most regulators across the world, capital calculated using a PD totally dependent on the prevailing economic conditions will provoke a high volatility in banks' solvency with the undesirable consequences that this effect implies.

It is important to note that if the capital figure for 2004 (1.04\%) is compared to the current regime figure for mortgage loans (around 4\%), one may get a rough idea of where the important reductions in capital requirements, anticipated by exercises such as the Quantitative Impact Studies (QIS) carried out by the BCBS, can be found. Average requirements along the cycle (1.56\%, calculated using the PIT sample average), are much lower than the capital figure that the Standardized Approach of Basel II (SA) demands and very far indeed from the current one. The main conclusion from the use of such PDs is that supervisors via Pillar 2 would have to perform or articulate some measure to try to reduce the dispersion shown and to maintain an acceptable level of one of the most important elements that determines the soundness and stability of banks' financial condition.

TTC PDs have several important properties, as can be seen in Table 4, second column. In the first place, much of the dispersion that PIT PDs incorporate disappears. This is the result of how TTC PDs are calculated. The inclusion of the worst record of the business cycle in the PD equation assures that at the trough of the business cycle the amount of capital will totally cover the losses that the Basel II formulas stipulate at the $99.9 \%$ percentile (i.e. the excess over the expected losses which, in principle, are covered by provisions).

18. Altman et al. (2005) study the relationship between PDs and LGDs for corporate bonds. 
On the other hand, as the cycle moves towards its most benign part, the most adverse GDP growth rate figure in the PD equation partly compensates for the improvement experienced by the rest of the explanatory variables. This partial balance provokes a lower reduction in capital required and results in a lower associated volatility. Similarly, if the cycle moves into a new recession, the progressive deterioration of the rest of the variables will gradually increase the capital required as prevailing conditions deteriorate with no major variations from one period to the next. It can also be seen that the current capital requirements for the more advanced approaches of Basel II are one percentage point under those arising from the Standardized Approach (1.84\% versus 2.8\%), and are even less than half of those coming from the current capital regime (4\%).

In a similar vein, a PD based on a long-run average (in principle, that proposed by the BCBS to be used as the input for the credit capital requirement formulas) would normally produce similar results to the TTC PD described above. However this measure will never exactly reproduce the requirements needed to cover the unexpected losses at the $99.9 \%$ percentile at the trough of the business cycle, simply because of the way it is calculated. On the other hand, the requirements for boom periods will be lower than those obtained from a TTC PD, since the further the distance from the trough the more similar the long-run estimates are to those coming from a PIT PD. This fact translates into a higher variation of capital over the business cycle. The current IRB capital figure that would derive from this method of calculation would be, to some extent, lower than the figure coming from the Standardized Approach (40\% lower) and almost 60\% less than the current capital regime figure.

Finally, the PDs corrected for the cycle (column 4 in Table 4) or those defined as acyclical (column 5 in Table 4) produce fairly similar results. It seems that when the variable representing the business cycle is set to its average value over the sample period, the effect on the estimated PDs is similar to the one that would take place when the cycle is obviated. The variability observed for these approaches is much lower than that in any other possibilities in which PDs can be calculated. However, at the trough of the business cycle these methods are those which seem to be least from adequate to cover the part of the unexpected losses associated with the $99.9 \%$ percentile. On the other hand, for the most favourable part of the cycle, the estimated PDs are much more similar to the real ones (PIT ones). As just said, the dispersion of this approach is the lowest. However, the omission of the cycle prevents from covering an important part of the losses that could take place and that could provoke solvency problems in case of severe adverse events.

All the capital figures presented so far have been calculated considering PD averages. However, banks will not use this type of estimates to determine their regulatory capital requirements. Instead, for IRB purposes, banks will be required to employ their own rating systems. These are risk classification devices which discriminate borrowers according to their creditworthiness and, accordingly, assign them into different risk buckets. Each bucket represents an homogenous credit risk group and is characterized by an associated probability of default which depends crucially on both the nature of the rating system (PIT, TTC, average rating....) and how it is used to calculate the corresponding PD estimate (as described above in terms of average PDs, e.g. PIT, TTC, long-run, corrected for the cycle, ....).

Notwithstanding that, the developing of a meaningful and consistent rating system, including the choice of the optimal number of risk buckets, is beyond the objectives of this 
paper since that increases complexity significantly without achieving results much different from those commented so far using average PDs regarding the discussion on the issue of procyclicaltiy related to Basel II.

Nevertheless, we tested the robustness of Table 4 results by developing, on the one hand, a tentative PIT rating system ${ }^{19}$, and on the other hand, an extreme case example which considers capital requirements directly calculated from individual obligors' PD estimates. In this latter case, we calculate the capital figure for the whole mortgage portfolio by adding each borrower's capital requirements weighted by her/his exposure with regard to the total exposure of the entire portfolio. Alternatively, capital requirements from the rating system are calculated by applying the average PD of each risk bucket to the exposure of all obligors that fall in each risk class proportionally to the total exposure of the whole portfolio.

The results obtained show that the capital figure derived from the rating system is similar, although somehow lower, to that obtained by using an average PD, while that calculated for the extreme case of individual PD estimates is much lower ${ }^{20}$ (a maximum capital figure of $1.5 \%$ in bad times and a minimum of $0.7 \%$ in good times). Despite the relatively lower levels of capital requirements for these two cases, recorded variability along the sample period (business cycle), is, as for the above mentioned case regarding sample average PDs, very high.

Since the purpose of this paper is to address and analyse variability and dispersion of capital figures along time depending on the method PDs are computed, the utilisation of sample average PDs to obtain capital requirements, as shown in Table 4 and Figure 2, although simple, seems a reasonable approximation (sufficiently informative) to discuss the procyclicality issue of regulatory capital regarding Basel II.

\subsection{Discussion on procyclicality}

The foregoing sections have shown that capital requirements under Basel II for mortgages significantly change depending on the method used by banks for calculating their credit risk parameters, namely, their PDs. The first lesson to be learned is that variability may be an important caveat as observed in the mortgage portfolio for the entire system and that the reduction in capital figures, considering possible estimates of measures of risk, could rise up to $75 \%$ with respect to the current capital regime. The use of PIT PDs is the extreme case, with significant variations across the business cycle.

The second important idea that can be obtained from these results is the wide dispersion that can exist among banks when producing regulatory capital measures regarding Basel II and that may not correspond to real differences in borrowers' risk profiles. Supervisors must be sure of the accuracy, reliability and application of the inputs that banks may use to determine IRB capital requirements. The previous section contained a very clear illustration of this situation: if capital is calculated using a PIT PD the resulting figure is $45 \%$ lower than that obtained if a TTC PD was used (a similar reduction is observed if a long-run average was used instead). This enormous variation in different ways of calculating measures of risk (all of them related, in one way or another, to the prevailing conditions of

19. Such a rating system is based on nine buckets, the last one for defaulted loans, showing an exponentially growing PD while exposures across buckets follows a normal distribution, which are the two basic hypotheses underlying any rating system.

20. The reason for this reduction in capital lies in the concavity of the IRB capital functions 
the economic cycle) must pose the question of which of them, if any, should be the most appropriate to determine capital figures.

PIT PDs have important properties and are basically those that banks work with when applying their scoring/rating systems either for pricing or making the decision whether or not to grant a loan to a possible customer. Additionally, they allow for cross comparison among banks of their credit risk profiles and, as a result, produce accurate and homogenous assessments of the risk incurred by each bank. However, it seems highly unlikely that supervisors will be prepared to accept such a measure for computing capital, because of the high variability that it contains which is reflected in capital requirements under the Basel II formulas.

Several options are open to try to work out this caveat: for example, those pointed out in Gordy and Howells (2006) by means of smoothing the final output through a countercyclical capital requirement formula in Pillar 2. Jiménez and Saurina (2006) argue for a countercyclical loan loss provision. However, the same mechanism or a similar one could be used for capital requirements in Pillar 2. That countercyclical mechanism would be transparent and, thus, not hamper Pillar 3 market discipline, which seems to be one of the main worries in Gordy and Howells (2006) who postulate the smoothing of the output but not of the inputs.

TTC PDs may not be the answer to the previous question either, since the level of requirements is quite above any other measure, especially for the benign part of the business cycle. Banks could be asked for a high level of capital when clearly it is not required given the level of actual risk. However, this measure assures that at the trough of the business cycle, losses will be covered (under the Basel II framework) with a 99.9\% probability. A trade-off comes up in this situation: enjoying a high probability of covering losses when most needed, as against requiring banks to maintain a buffer of excess of capital over their real needs.

Although counterintuitive, this type of risk measure also discriminates between the degree of risk each bank incurs. PIT PDs reflect both current economic and obligor-specific conditions whereas $\Pi T C$ ones only reflect the latter as all banks share in the PD equation the same value for the cycle variable (the most adverse one in the sample period). Nevertheless, in terms of creditworthiness, both measures incorporate valid information to classify obligors with respect to the inherent risk that their profile presupposes.

Finally, it is also important to take into account the asymmetry in requirements that this measure produces. As said before, by using a TTC PD, supervisors can be sure that for a recession period, capital required will be in line with the real needs that the economic situation implies. On the other hand, the misallocation of capital only comes during upturns. This could be considered as a price for a lower level of volatility in capital figures anticipating possible future bad times, when raising capital could be much harder to obtain (and in any case, far more expensive) than maintaining a higher amount in good times.

Long-run averages share most of the properties of TTC PDs as commented above. Based on the particular way they are constructed, they are less demanding for banks since for upturns they will be more similar to PIT PDs and, consequently, the capital figures will be much lower than those calculated using TTC PDs. Their main drawback arises in downturns when the amount of capital will not assure with a $99.9 \%$ probability that 
losses will be covered. From a supervisory perspective long-run averages fall short of the most important advantage of TTC PDs without significantly improving its main caveat. Other things being equal, TTC PDs, as presented in this paper, seem superior to long-run averages.

In principle, acyclical PDs should be the most preferred measure whenever the model that produces them carefully sets aside the cyclical effect without totally ignoring its consequences. If a rating system could get rid of the fluctuations that the cycle incorporates and appropriately estimate the risk profile of obligors, via their idiosyncratic features, this could avoid extreme swings in PDs and in required capital. This may constitute the solution regulators are looking for. The deterioration of the prevailing economic conditions would make obligors migrate to lower credit quality categories implying higher average PDs for the entire portfolio, and the opposite would happen in boom periods. Acyclical measures would probably be the most effective, still allowing for certain variability in capital requirements, but without the huge swings that PIT PDs seem to produce.

A half-way compromise might be to use a through-the-cycle approach but based not on the worst position in the cycle but on a somehow less extreme approach. That might produce significantly higher capital than required in expansions while still producing greater capital in recessions, but without the high level in average terms that a pure $T \mathrm{CC}$ approach requires. 


\section{Conclusions}

This paper provides a simple methodology for banks and bank supervisors to analyze procyclicality of Basel II capital requirements. We focus on mortgages, one of the most under researched areas of Basel II, even despite the fact that for many banks, they are one of their largest credit portfolios. We take advantage of the Spanish Credit Register, a comprehensive database that contains loan and borrower information (including credit risk performance) for the last twenty years (i.e. almost two business cycles).

We estimate a probability of default model for mortgages, using information of roughly 3 million borrowers. This model includes several risk profile variables (liquidity constraints and default and delinquency past history of each borrower) and a macro variable (GDP growth rate) and allows us to assign to each individual a single probability of default. Based on these probabilities and on different approaches, depending on the nature of the measure to be calculated, we obtain distinct averages that allow us to study their properties and adequacy for regulatory capital.

In short, we compare point-in-time, through-the-cycle, long-run averages, cyclically corrected, and acyclical PDs. The comparison of these approximations to measure credit risk, provides us with evidence which translates into a highly significant variability, in particular of point-in-time PDs, along the cycle with huge changes in capital requirements from peak (expansion) to trough (recession). That variability raises a concern for supervisors who aim to apply the more advanced approaches included in Basel II.

Through-the-cycle measures show much less variability, although the average level of capital requirements is relatively high. Acyclical ratings produce stable and relatively low requirements. Thus, a reasonable compromise might be the use of $\Pi \mathrm{TC}$ ratings, but not using the worst point in the cycle to compute them. An alternative compromise might well be the use of acyclical PD measures which share most of their properties with TTC PDs with the advantage of being more benign, in terms of required capital, during upturns. However, attention should be paid in the way the cyclical effect is taken out when estimating those PDs.

All in all, we show that Basel II procyclicality is an open issue that deserves careful scrutiny for mortgage portfolios and, by extension, for corporate and retail ones. In any case, the Basel II framework has within itself the mechanism to deal with this issue (i.e. rating system properties and supervisory implementation). 


\section{REFERENCES}

ALLEN, L. (2004). "The Basel capital accords and International mortgage markets: A survey of the literature", Financial Markets, Institutions \& Instruments, Vol. 13, No. 2, May.

ALLEN, L., and A. SAUNDERS (2004). "Incorporating systemic influences into risk measurements: a survey of the literature", Journal of Financial Services Research, 26, 2, pp. 161-192.

ALTMAN, E. I., B. BRADY, A. RESTI and A. SIRONI (2005). "The link between default and recovery rates: theory, empirical evidence, and implications", Journal of Business, Vol. 78, No. 6.

ALTUMBAS, Y., O. FAZYLOW and P. MOLINEUX (2002). "Evidence on the bank lending channel in Europe", Journal of Banking and Finance, 26, pp. 2093-2110.

AMATO, J. D., and C. H. FURFINE (2004). Are credit ratings procyclical, BIS Working Paper.

AYUSO, J., D. PÉREZ and J. SAURINA (2004). "Are capital buffers procyclical? Evidence from Spanish panel data", Journal of Financial Intermediation, 13, pp. 249-264.

BASEL COMMITTEE ON BANKING SUPERVISION (2006a). Results of the fifth quantitative impact study (QIS 5), BIS, June.

- (2006b). International Convergence of Capital Measurement and Capital Standards, BIS.

BERGER, A. N., and G. F. UDELL (1994). "Did risk-based capital allocate bank credit and cause a "credit crunch" in the United States?", Journal of Money, Credit and Banking, 26, No. 3, Part. 2, pp. 585-628.

BERNANKE, B. S., and C. LOWN (1991). "The credit crunch", Brookings Papers on Economic Activity, 2.

BORIO, C., C. FURFINE and P. LOWE (2001). Procyclicality of the financial system and financial stability: issues and policy options, BIS.

CALEM, P. S., and M. LACOUR-LITTLE (2004). "Risk-based capital requirements for mortgage loans", Journal of Banking \& Finance, 28, pp. 647-672.

CATARINEU-RABELL, E., P. JACKSON and D. TSOMOCOS (2005). "Procyclicality and the new Basel Accord-banks' choice of loan rating system", Economic Theory, 26, pp. 537-557.

DELGADO, J., V. SALAS and J. SAURINA (2006). The joint size and ownership specialization in banks' lending, Working Paper No. 0606, Banco de España..

DIETSCH, M. and J. PETEY (2002). "The credit risk in SME loans portfolios: Modelling issues, pricing and capital requirements", Journal of Banking and Finance, Vol. 24.

EHRMANN, M., L. GAMBACORTA, J. MARTÍNEZ and P. SEVESTRE (2003). "Financial systems and the role of banks in monetary policy transmission in the euro area", in I. Angeloni, A. Kashyap and B. Mojon (eds.), Monetary Policy Transmission in the Euro Area, Cambridge Univ. Press, Cambridge, pp. 235-269.

ERVIN, W., and T. WILDE (2001). "Pro-cyclicality in the new Basel Accord", Risk.

GAMBACORTA, L., and P. E. Mistrulli (2004). "Does bank capital affect lending behaviour?", Journal of Financial Intermediation, 13, pp. 436-457.

GOODHART, C. (2005). "Financial regulation, credit risk and financial stability", National Institute Economic Review, 192, April.

GOODHART, CH., B. HOFMANN and M. SEGOVIANO (2004). "Bank regulation and macroeconomic fluctuations", Oxford Review of Economic Policy, 20, No. 4.

GORDY, M. B., and B. HOWELLS (2006). "Procyclicality in Basel II: Can we treat the disease without killing the patient?", Journal of Financial Intermediation, 15, 3, pp. 395-417.

GROSS, D. B., and N. S. SOULELES (2002). "Am empirical analysis of personal bankruptcy and delinquency", The Review of Financial Studies, 15, No. 1, Spring, pp. 319-347

HEITFIELD, E. (2005). Draft on the role of internal rating systems in credit-risk management, Federal Reserve Board.

JACOBSON, T., L. JESPER and K. ROSZBACH (2006). "Credit Risk Versus Capital Requirements Under Basel II: Are SME Loans and Retail Credit Really Different?”, Journal of Financial Services Research, 28, No.1/2, pp. 43-75.

JIMÉNEZ, G., V. SALAS and J. SAURINA (2006). "Determinants of collateral", Journal of Financial Economics, 81, pp. 255-281.

JIMÉNEZ, G., and J. SAURINA (2004). "Collateral, type of lender and relationship banking as determinants of credit risk", Journal of Banking and Finance, 28, pp. 2191-2212.

- (2006). "Credit cycles, credit risk and prudential regulation", International Journal of Central Banking, Vol. 2, No. 2 June, pp. 65-98.

KASHYAP, A. K., and J.C. STEIN (2004). "Cyclical implications of the Basel II capital standards", Economic Perspectives, 1Q/2004, Federal Reserve Board of Chicago.

LANG, W. W., L. J. MESTER and T. A. VERMILYEA (2006). Competitive effects of Basel II on U.S. Bank credit card lending, May.

MADAN D. B., and H. UNAL (2006). Designing countercyclical and risk based aggregate deposit insurance premia, September.

PEEK, J., and E. ROSENGREN (1995). "The capital crunch: neither a borrower nor a lender be", Journal of Money, Credit and Banking, 27, No. 3, August, pp. 625-638.

PENNACCHI, G. G. (2005). "Risk-based capital standards, deposit insurance, and procyclicality", Journal of Financial Intermediation, Vol. 14, pp. 432-465.

REPULLO, J., and J. SUÁREZ (2006). Procyclicality of bank capital regulation, mimeo.

SAURINA, J., and C. TRUCHARTE (2004). "The small and medium-sized enterprises in the Spanish credit system and their treatment according to Basel II", Journal of Financial Services Research, 26, No. 2, pp. 121-144.

SEGOVIANO, M. A., and P. LOWE (2002). Internal ratings, the business cycle and capital requirements: some evidence from an emerging market economy, Draft. 
TAYLOR, A., and C. GOODHART (2004). Procyclicality and volatility in the financial system: The implementation of Basel II and IAS 29, Preliminary draft.

TRUCHARTE, C. (2004). A review of Credit Registers and their use for Basel II, Financial Stability Institute, BIS, September.

VIÑALS, J. (2006). "Comments on Procyclicality and Volatility in the Financial System", in S. Gerlach and P. Gruenwald (eds.), Procyclicality of Financial Systems in Asia, IMF and HKIMR.

WHITE, W. R. (2006). Procyclicality in the financial system: do we need a new macrofinancial stabilisation framework? BIS Working Papers, No. 193. 
Table 1. Descriptive characteristics of the population and the sample used

Each row presents both for the whole population and for the sample of borrowers to be used to estimate the PD model the following information: the total number of mortgages loans (Total Operations); the exposure they represent (in thousand euros); the average value of a mortgage (in thousand euros); the value of a mortgage in the $90^{\text {th }}$ percentile (in thousand euros); the value of the problem loans ratio (value of defaulted loans divided by the total value of mortgage loans) and the proportion of defaults (number of defaulted borrowers over the total number of borrowers).

$\begin{array}{lrrcccc}\text { Year } & \begin{array}{c}\text { Total } \\ \text { Operations }\end{array} & \begin{array}{c}\text { Exposure } \\ \text { (thousand } € \text { ) }\end{array} & \begin{array}{c}\text { Average loan } \\ \text { (thousand } € \text { ) }\end{array} & \begin{array}{c}\text { 90th } \\ \begin{array}{c}\text { Percentile } \\ \text { (thousand } € \text { ) }\end{array}\end{array} & \begin{array}{c}\text { Problem } \\ \text { loans ratio }\end{array} & \begin{array}{c}\text { Proportion } \\ \text { of defaults }\end{array} \\ 1990 & 1,095,881 & 17,900,000 & 16.4 & 30.0 & 4.0 \% & 3.4 \% \\ 1990 \text { sample } & 109,803 & 1,800,348 & 16.4 & 30.0 & 4.0 \% & 3.3 \% \\ 1993 & 1,792,216 & 33,100,000 & 18.5 & 36.0 & 4.2 \% & 3.6 \% \\ 1993 \text { sample } & 179,814 & 3,328,174 & 18.5 & 36.0 & 4.2 \% & 3.6 \% \\ 1997 & 3,967,016 & 82,100,000 & 20.7 & 42.0 & 0.9 \% & 0.9 \% \\ 1997 \text { sample } & 396,034 & 8,220,267 & 20.8 & 42.0 & 0.9 \% & 0.9 \% \\ 2001 & 5,787,661 & 162,000,000 & 28.0 & 55.0 & 0.4 \% & 0.7 \% \\ 2001 \text { sample } & 578,260 & 16,200,000 & 28.0 & 55.0 & 0.4 \% & 0.7 \%\end{array}$


Table 2a. Estimation of the logit model (1) by maximum likelihood

$P D_{i t}=\beta_{1} R I S K B O R R_{i t}+\beta_{2} L_{I Q B O R R_{i t}}+\beta_{3} G D P G_{t}+\beta_{4} C O N T R O L+\eta_{i t}$

This table presents the results of the estimation of the above equation. The GDP growth rate represents the rate of growth of the Gross National Product. DEHFIST informs whether or not a certain borrower has defaulted in any period earlier to the one used to fix the assessment period for calculating each borrower PD. OVERHIST stands for possible delinquency of a borrower in history. CHANOVERHIST is the rate of variation of OVERHIST. AGE accounts for the age of each loan. UTIL represents the quotient between the amount of credit drawn and the total amount of credit. NUMBANKS is the number of banks with which each borrower has lending relationships. Dumreg_99 is a dummy variable which reflects the change in the report in defaulted loans after 1999. Regional dummies account for the region of the borrower while Type of lender dummies differentiates the nature (ownership) of the lender.

No. of observations: 2,936,193. Sampling period: 1990-2004. In parenthesis is the standard error of the coefficient. All variables are significant at the $99 \%$ confidence level.

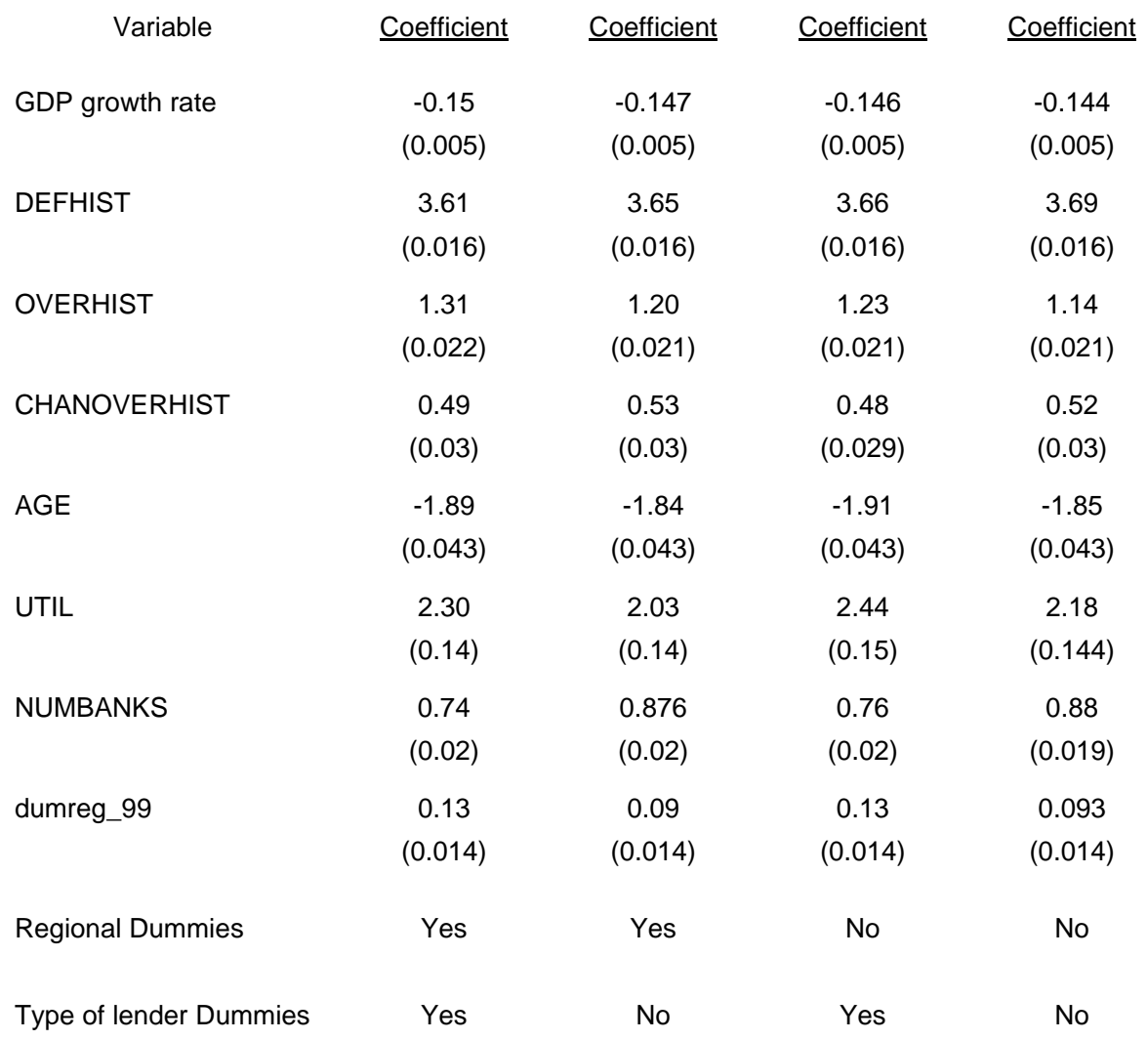


Table 2b. Logit Model Performance

This table reports the performing power of the regression model. It provides the figure of correctly classified defaulted borrowers (combination of the columns headed "observed defaults" and "predicted defaults"). It is also provided the proportion of correctly classified non-defaulted borrowers (combination of the columns headed "observed non-defaults" and "predicted non-defaults") and implicitly the ratio of correctly classified borrowers by the regression model (sum of the combination of the columns headed "observed defaults" and "predicted defaults" and the combination of the columns headed "observed non-defaults" and "predicted non-defaults" over the total number of borrowers). It is also shown the ROC curve value and the Accuracy Ratio.

\begin{tabular}{|c|c|c|c|}
\hline & & & \\
\hline & & & \\
\hline & $\begin{array}{l}\text { Observed } \\
\text { Defaults }\end{array}$ & $\begin{array}{l}\text { Observed } \\
\text { Non-defaults }\end{array}$ & Total \\
\hline Predicted & 19,009 & 681,114 & 700,123 \\
\hline Defaults & $64.50 \%$ & $23.00 \%$ & \\
\hline Predicted & 10,447 & $2,280,541$ & $2,291,018$ \\
\hline Non-defaults & $35.50 \%$ & $77.00 \%$ & \\
\hline Total & 29,486 & $2,961,655$ & $2,991,141$ \\
\hline
\end{tabular}

Area under ROC curve $=0.78$.

Accuracy ratio $=57 \%$. 


\section{Table 3. Probabilities of default (PDs) along the cycle}

Probabilities of default are reported per annum. PIT PDs are calculated by dividing the number of obligors which default in a certain year by the total number of obligors. The yearly TTC PD is the simple average of the predicted PD for each borrower using model (1) estimates when the value of the cyclical variable, GDP growth rate, is fixed at its most adverse sample value. Long-run-average PDs are obtained by calculating the cumulative average of the yearly averages of the predicted PD for each borrower using model (1) estimates. Cyclically corrected yearly PDs are obtained by calculating the simple average of the fitted PDs for each borrower using model (1) when the value of the GDP growth rate is fixed at its sample average value. Finally, the acyclical PD is the annual average of borrower's predicted PDs when the effect of the cyclical variable has been omitted. The last two rows of the table show the sample average (1991-2004 simple average) and its standard deviation for each of the above-described PDs.

$\begin{array}{cccccc} & \text { PD } & \text { PD } & \text { PD } & \text { PD } & \text { PD } \\ \text { Year } & \text { PIT } & \text { TTC } & \begin{array}{c}\text { Long-run } \\ \text { average }\end{array} & \begin{array}{c}\text { Cyclically } \\ \text { corrected }\end{array} & \text { Acyclical } \\ 1991 & 2.27 \% & 2.49 \% & 2.41 \% & 1.55 \% & 1.62 \% \\ 1992 & 2.55 \% & 2.80 \% & 2.55 \% & 1.77 \% & 1.85 \% \\ 1993 & 2.91 \% & 2.56 \% & 2.73 \% & 1.61 \% & 1.68 \% \\ 1994 & 2.18 \% & 2.33 \% & 2.55 \% & 1.46 \% & 1.51 \% \\ 1995 & 1.24 \% & 2.30 \% & 2.22 \% & 1.44 \% & 1.49 \% \\ 1996 & 0.96 \% & 2.04 \% & 1.97 \% & 1.25 \% & 1.29 \% \\ 1997 & 0.61 \% & 1.87 \% & 1.74 \% & 1.13 \% & 1.17 \% \\ 1998 & 0.41 \% & 1.60 \% & 1.55 \% & 0.95 \% & 0.98 \% \\ 1999 & 0.49 \% & 1.61 \% & 1.49 \% & 0.95 \% & 0.92 \% \\ 2000 & 0.66 \% & 1.58 \% & 1.43 \% & 0.93 \% & 0.90 \% \\ 2001 & 0.59 \% & 1.54 \% & 1.37 \% & 0.92 \% & 0.88 \% \\ 2002 & 0.54 \% & 1.49 \% & 1.32 \% & 0.88 \% & 0.85 \% \\ 2003 & 0.44 \% & 1.41 \% & 1.27 \% & 0.84 \% & 0.81 \% \\ 2004 & 0.58 \% & 1.36 \% & 1.22 \% & 0.80 \% & 0.77 \% \\ \text { Sample average } & 1.05 \% & 1.88 \% & 1.80 \% & 1.15 \% & 1.19 \% \\ \text { Std.dev. } & 0.90 \% & 0.49 \% & 0.55 \% & 0.33 \% & 0.37 \%\end{array}$


Table 4. Basel II capital requirements (annual averages)

Each row of this table reveals the yearly capital figure using the IRB Basel II formula for mortgage loans when different types of annual average PDs are used: point-in-time (PIT), through-the-cycle (TTC), long-run average, corrected for the cycle (cyclically corrected) and acyclical. The last three rows present the sample average (1991-2004 simple average), its standard deviation and the range of variation for each capital figure using as input for its computation each of the annual average PDs described above. The range of variation is defined as the maximum observed variation in value for each capital figure.

$\begin{array}{cccccc} & \text { PD } & \text { PD } & \text { PD } & \text { PD } & \text { PD } \\ \text { Year } & \text { PIT } & \text { TTC } & \begin{array}{c}\text { Long-run } \\ \text { average }\end{array} & \begin{array}{c}\text { Cyclically } \\ \text { corrected }\end{array} & \text { Acyclical } \\ 1991 & 2.53 \% & 2.68 \% & 2.63 \% & 2.00 \% & 2.06 \% \\ 1992 & 2.72 \% & 2.87 \% & 2.72 \% & 2.17 \% & 2.24 \% \\ 1993 & 2.93 \% & 2.72 \% & 2.83 \% & 2.05 \% & 2.11 \% \\ 1994 & 2.47 \% & 2.57 \% & 2.71 \% & 1.93 \% & 1.97 \% \\ 1995 & 1.73 \% & 2.55 \% & 2.50 \% & 1.91 \% & 1.95 \% \\ 1996 & 1.46 \% & 2.37 \% & 2.32 \% & 1.74 \% & 1.78 \% \\ 1997 & 1.07 \% & 2.25 \% & 2.15 \% & 1.63 \% & 1.66 \% \\ 1998 & 0.81 \% & 2.04 \% & 2.00 \% & 1.46 \% & 1.48 \% \\ 1999 & 0.92 \% & 2.05 \% & 1.95 \% & 1.45 \% & 1.42 \% \\ 2000 & 1.14 \% & 2.02 \% & 1.90 \% & 1.44 \% & 1.40 \% \\ 2001 & 1.06 \% & 1.99 \% & 1.85 \% & 1.42 \% & 1.38 \% \\ 2002 & 0.99 \% & 1.95 \% & 1.80 \% & 1.38 \% & 1.35 \% \\ 2003 & 0.85 \% & 1.89 \% & 1.76 \% & 1.34 \% & 1.30 \% \\ 2004 & 1.04 \% & 1.84 \% & 1.71 \% & 1.30 \% & 1.26 \% \\ \text { Sample average } & 1.56 \% & 2.26 \% & 2.20 \% & 1.65 \% & 1.69 \% \\ \text { Std.dev. } & 0.77 \% & 0.35 \% & 0.40 \% & 0.30 \% & 0.34 \% \\ \text { Variation range } & 2.12 \% & 1.03 \% & 1.11 \% & 0.88 \% & 0.98 \%\end{array}$


Figure 1. PDs and GDP growth rate

This figure presents (left axis) the level and shape of the different types of PDs obtained from equation (1).These are: point-in-time, PIT, through-the-cycle, TTC, long-run-average, corrected for the cycle (cyclically corrected) and acyclical. The GDP growth rate is depicted in the right axis.

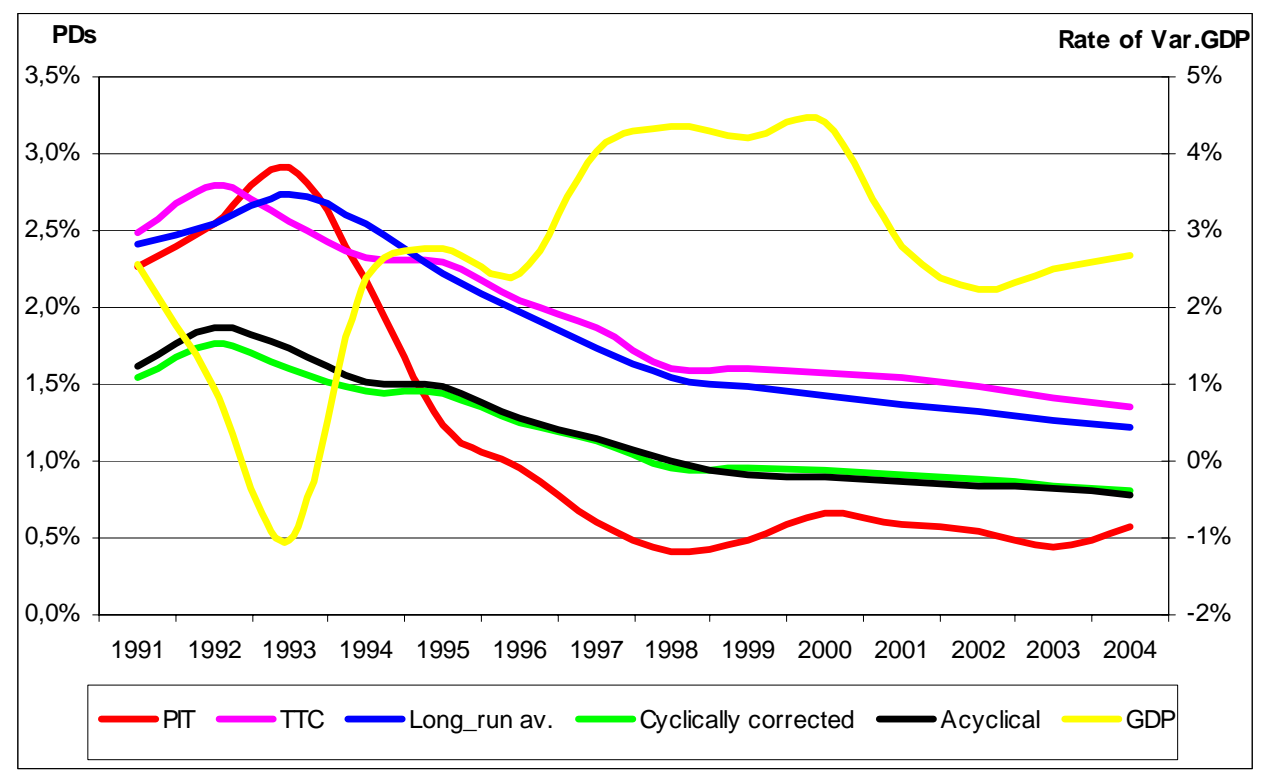


Figure 2. Capital requirements (sample averages)

This figure depicts the yearly capital figure using the IRB Basel II formula for mortgage loans when different types of annual average PDs are used: point-in-time (PIT), through-the-cycle (TTC), long-run average, corrected for the cycle (cyclically corrected) and acyclical.

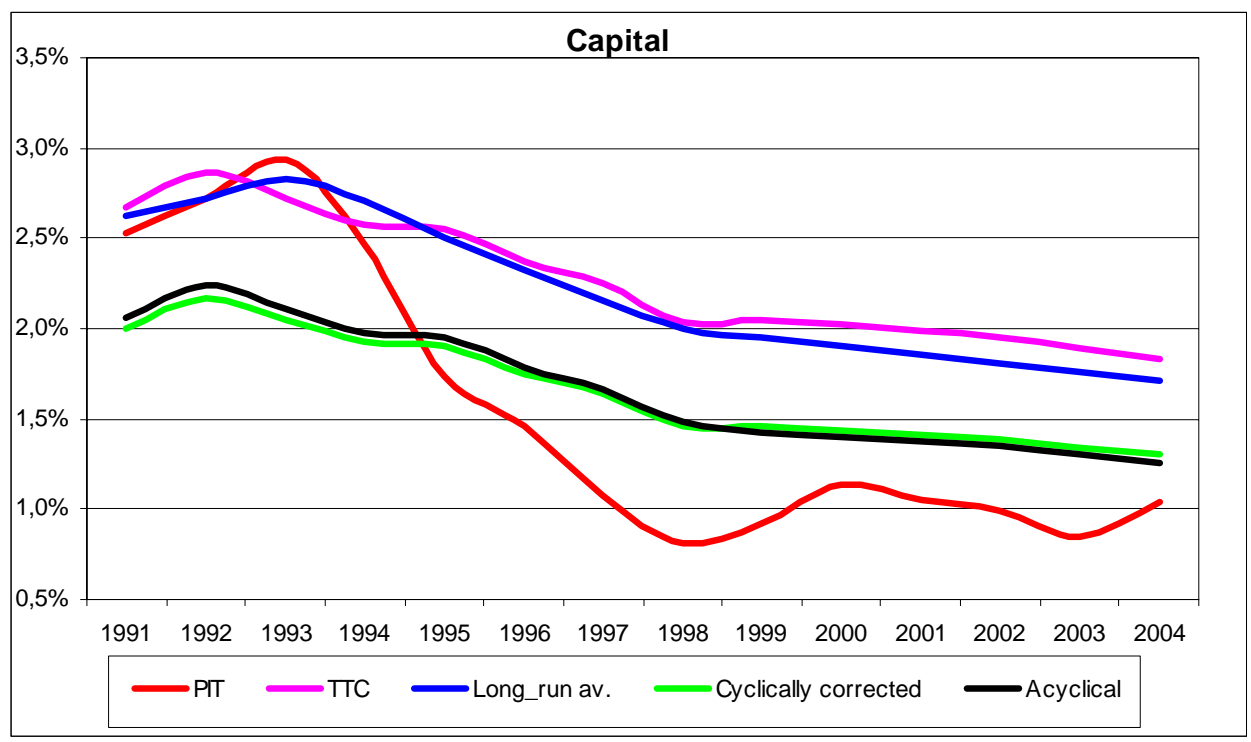




\section{BANCO DE ESPAÑA PUBLICATIONS}

\section{WORKING PAPERS ${ }^{1}$}

0601 ARTURO GALINDO, ALEJANDRO IZQUIERDO AND JOSÉ MANUEL MONTERO: Real exchange rates, dollarization and industrial employment in Latin America.

0602 JUAN A. ROJAS AND CARLOS URRUTIA: Social security reform with uninsurable income risk and endogenous borrowing constraints.

0603 CRISTINA BARCELÓ: Housing tenure and labour mobility: a comparison across European countries.

0604 FRANCISCO DE CASTRO AND PABLO HERNÁNDEZ DE COS: The economic effects of exogenous fiscal shocks in Spain: a SVAR approach.

0605 RICARDO GIMENO AND CARMEN MARTÍNEZ-CARRASCAL: The interaction between house prices and loans for house purchase. The Spanish case.

0606 JAVIER DELGADO, VICENTE SALAS AND JESÚS SAURINA: The joint size and ownership specialization in banks' lending.

0607 ÓSCAR J. ARCE: Speculative hyperinflations: When can we rule them out?

0608 PALOMA LÓPEZ-GARCÍA AND SERGIO PUENTE: Business demography in Spain: determinants of firm survival.

0609 JUAN AYUSO AND FERNANDO RESTOY: House prices and rents in Spain: Does the discount factor matter?

0610 ÓSCAR J. ARCE AND J. DAVID LÓPEZ-SALIDO: House prices, rents, and interest rates under collateral constraints.

0611 ENRIQUE ALBEROLA AND JOSÉ MANUEL MONTERO: Debt sustainability and procyclical fiscal policies in Latin America.

0612 GABRIEL JIMÉNEZ, VICENTE SALAS AND JESÚS SAURINA: Credit market competition, collateral and firms' finance.

0613 ÁNGEL GAVILÁN: Wage inequality, segregation by skill and the price of capital in an assignment model.

0614 DANIEL PÉREZ, VICENTE SALAS AND JESÚS SAURINA: Earnings and capital management in alternative loan loss provision regulatory regimes.

0615 MARIO IZQUIERDO AND AITOR LACUESTA: Wage inequality in Spain: Recent developments.

0616 K. C. FUNG, ALICIA GARCÍA-HERRERO, HITOMI IIAKA AND ALAN SUI: Hard or soft? Institutional reforms and infraestructure spending as determinants of foreign direct investment in China.

0617 JAVIER DÍAZ-CASSOU, ALICIA GARCÍA-HERRERO AND LUIS MOLINA: What kind of capital flows does the IMF catalyze and when?

0618 SERGIO PUENTE: Dynamic stability in repeated games.

0619 FEDERICO RAVENNA: Vector autoregressions and reduced form representations of DSGE models.

0620 AITOR LACUESTA: Emigration and human capital: Who leaves, who comes back and what difference does it make?

0621 ENRIQUE ALBEROLA AND RODRIGO CÉSAR SALVADO: Banks, remittances and financial deepening in receiving countries. A model.

0622 SONIA RUANO-PARDO AND VICENTE SALAS-FUMÁS: Morosidad de la deuda empresarial bancaria en España, 1992-2003. Modelos de la probabilidad de entrar en mora, del volumen de deuda en mora y del total de deuda bancaria, a partir de datos individuales de empresa.

0623 JUAN AYUSO AND JORGE MARTíNEZ: Assessing banking competition: an application to the Spanish market for (quality-changing) deposits.

0624 IGNACIO HERNANDO AND MARÍA J. NIETO: Is the Internet delivery channel changing banks' performance? The case of Spanish banks.

0625 JUAN F. JIMENO, ESTHER MORAL AND LORENA SAIZ: Structural breaks in labor productivity growth: The United States vs. the European Union.

0626 CRISTINA BARCELÓ: A Q-model of labour demand.

0627 JOSEP M. VILARRUBIA: Neighborhood effects in economic growth.

0628 NUNO MARTINS AND ERNESTO VILLANUEVA: Does limited access to mortgage debt explain why young adults live with their parents?

0629 LUIS J. ÁLVAREZ AND IGNACIO HERNANDO: Competition and price adjustment in the euro area.

0630 FRANCISCO ALONSO, ROBERTO BLANCO AND GONZALO RUBIO: Option-implied preferences adjustments, density forecasts, and the equity risk premium.

1. Previously published Working Papers are listed in the Banco de España publications catalogue. 
0631 JAVIER ANDRÉS, PABLO BURRIEL AND ÁNGEL ESTRADA: BEMOD: A dsge model for the Spanish economy and the rest of the Euro area.

0632 JAMES COSTAIN AND MARCEL JANSEN: Employment fluctuations with downward wage rigidity: The role of moral hazard.

0633 RUBÉN SEGURA-CAYUELA: Inefficient policies, inefficient institutions and trade.

0634 RICARDO GIMENO AND JUAN M. NAVE: Genetic algorithm estimation of interest rate term structure.

0635 JOSÉ MANUEL CAMPA, JOSÉ M. GONZÁLEZ-MÍNGUEZ AND MARÍA SEBASTIÁ-BARRIEL: Non-linear adjustment of import prices in the European Union.

0636 AITOR ERCE-DOMÍNGUEZ: Using standstills to manage sovereign debt crises.

0637 ANTON NAKOV: Optimal and simple monetary policy rules with zero floor on the nominal interest rate.

0638 JOSÉ MANUEL CAMPA AND ÁNGEL GAVILÁN: Current accounts in the euro area: An intertemporal approach.

0639 FRANCISCO ALONSO, SANTIAGO FORTE AND JOSÉ MANUEL MARQUÉS: Implied default barrier in credit default swap premia. (The Spanish original of this publication has the same number.)

0701 PRAVEEN KUJAL AND JUAN RUIZ: Cost effectiveness of R\&D and strategic trade policy.

0702 MARÍA J. NIETO AND LARRY D. WALL: Preconditions for a successful implementation of supervisors' prompt corrective action: Is there a case for a banking standard in the EU?

0703 PHILIP VERMEULEN, DANIEL DIAS, MAARTEN DOSSCHE, ERWAN GAUTIER, IGNACIO HERNANDO, ROBERTO SABBATINI AND HARALD STAHL: Price setting in the euro area: Some stylised facts from individual producer price data.

0704 ROBERTO BLANCO AND FERNANDO RESTOY: Have real interest rates really fallen that much in Spain?

0705 OLYMPIA BOVER AND JUAN F. JIMENO: House prices and employment reallocation: International evidence.

0706 ENRIQUE ALBEROLA AND JOSÉ M. a SERENA: Global financial integration, monetary policy and reserve accumulation. Assessing the limits in emerging economies.

0707 ÁNGEL LEÓN, JAVIER MENCÍA AND ENRIQUE SENTANA: Parametric properties of semi-nonparametric distributions, with applications to option valuation

0708 DANIEL NAVIA AND ENRIQUE ALBEROLA: Equilibrium exchange rates in new EU members: external imbalances vs. real convergence.

0709 GABRIEL JIMÉNEZ AND JAVIER MENCÍA: Modelling the distribution of credit losses with observable and latent factors.

0710 JAVIER ANDRÉS, RAFAEL DOMÉNECH AND ANTONIO FATÁS: The stabilizing role of government size.

0711 ALFREDO MARTÍN-OLIVER, VICENTE SALAS-FUMÁS AND JESÚS SAURINA: Measurement of capital stock and input services of Spanish banks.

0712 JESÚS SAURINA AND CARLOS TRUCHARTE: An assessment of Basel II procyclicality in mortgage portfolios.

\begin{tabular}{|c|c|}
\hline $\begin{array}{r}\text { BANCODEESPAÑ } \\
\text { Eurosistema }\end{array}$ & $\begin{array}{c}\text { Unidad de Publicaciones } \\
\text { Alcalá, 522; } 28027 \text { Madrid } \\
\text { Telephone +3491338 6363. Fax +34 } 913386488 \\
\text { e-mail: publicaciones@bde.es } \\
\text { www.bde.es }\end{array}$ \\
\hline
\end{tabular}

